\title{
Ferrian Hydroxyl Topaz from a Carbonatite Lapillus from Thiuvalangadu, Tamil Nadu, India
}

\section{Ramachandran Ramasamy}

Project Advisor, National Centre for Safety in Heritage Structures, Department of Civil Engineering, Indian Institute of Technology-Madras, Chennai, India

\section{Email address: \\ drrramy@ymail.com}

\section{To cite this article:}

Ramachandran Ramasamy. Ferrian Hydroxyl Topaz from a Carbonatite Lapillus from Thiuvalangadu, Tamil Nadu, India. Science Discovery. Vol. 3, No. 6, 2015, pp. 50-54. doi: 10.11648/j.sd.20150306.12

\begin{abstract}
A plate like crystal $(2 \times 1.5 \times 0.2 \mu \mathrm{m})$ having prismatic and pyramidal faces is identified under scanning electron microscope attached with EDAX probe as a ferrian hydroxyl topaz with its structural formula $\mathrm{Si}_{4}\left(\mathrm{Si}_{1.172} \mathrm{Al}_{2.296} \mathrm{Fe}^{3+}{ }_{2.133}\right.$ $\left.\mathrm{Mg}_{0.307} \mathrm{Ca}_{0.347} \mathrm{Na}_{0.335} \mathrm{~K}_{0.293} \mathrm{Ti}_{0.088} \mathrm{P}_{0.053} \mathrm{SO}_{3}{ }_{0.079}\right)_{7.104}\left(\mathrm{~F}_{5.517} \mathrm{OH}_{5.482}\right)_{10.998}$ on the basis of 24(O, OH, F). It is found as interstitial mineral amidst calcite crystals. The bulk composition of carbonatite indicates that the topaz was formed by crystallization from a residual liquid derived from the carbonatite lava during the course of its rapid consolidation.
\end{abstract}

Keywords: Carbonatite Lava, Bimodal Volcanism, Ferrian Hydroxyl Topaz, Residual Fluids, Rapid Consolidation

\section{Introduction}

Around Thiruvalangadu, an occurrence of a basal conglomerate composed of both grey coloured and pink coloured carbonatitic lava materials (enriched with $\mathrm{U}, \mathrm{Pb}, \mathrm{Zr}$, $\mathrm{Hf}, \mathrm{Nb}, \mathrm{Ta}, \mathrm{REE}, \mathrm{Y}, \mathrm{Ba}, \mathrm{Sr}, \mathrm{P}, \mathrm{S}, \mathrm{F}$ etc.) cemented with medium grained to coarse grained sand, clay and calcareous materials (Figure 1 and 2) is exposed between Mio-Pliocene sandstone and boulder beds of Pleistocene $e^{1,2,3}$. The area of conglomerate occurrence exceeds over $90 \mathrm{~km}^{4}$. It appears that black or grey coloured carbonatite lava eruptions took place earlier and just before the eruptions of the pink coloured carbonatite lava in this area. Pink carbonatites are richer in silica and alkalies than grey carbonatites. Both black and pink coloured carbonatite lava materials are very fine-grained in nature. The crystalline feature of individual grains is visible only above the magnifications over 5000X. Size and shape of linear vesicles widely vary and parallel to the flow bandings of calcite microlites. They are essentially composed of calcites with accessories of olivine, alkali amphibole, biotite, wollastonite and quartz. Topaz is found very rarely. It has prismatic and pyramidal faces with well developed (001) cleavages. Its size is measured $2 \times 1.5 \mu \mathrm{m}$ at $10000 \mathrm{X}$ and it is observed in the pink carbonatite material (Fig. 1a). It is a plate like mineral (thickness $>0.2 \mu \mathrm{m}$ ) formed at the interstitial spaces of well developed calcite crystals with rhombohedral cleavages (Figure. 3a). Abundant free spaces are seen between intergranular boundaries and crystal imperfections of these calcite grains.

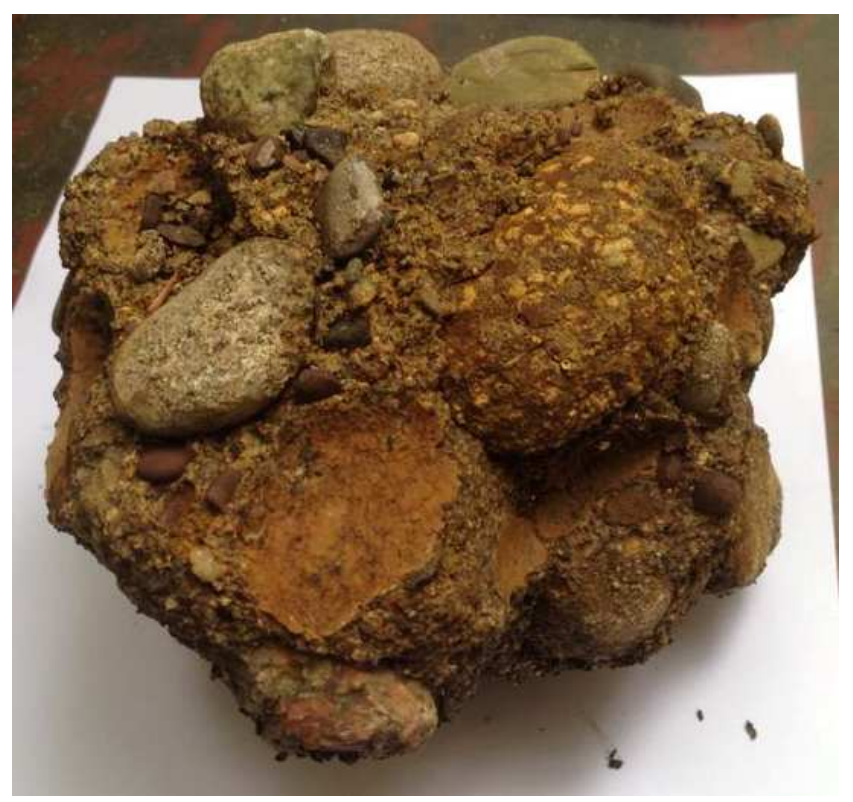

a

Figure 1a. Conglomerate composed of both grey and pink carbonatite lapillus, pisolites and ashes cemented with coarse grained sand, clay and calcareous materials, semi-unconsolidated. 


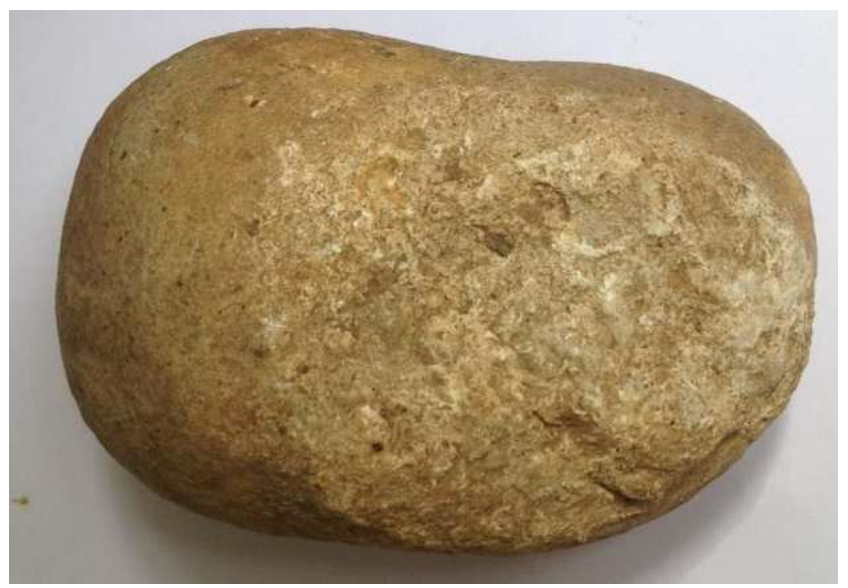

b

Figure 1b. A very fine-grained grey coloured carbonatitic lava bomb (>64mm) with smooth outer surface.

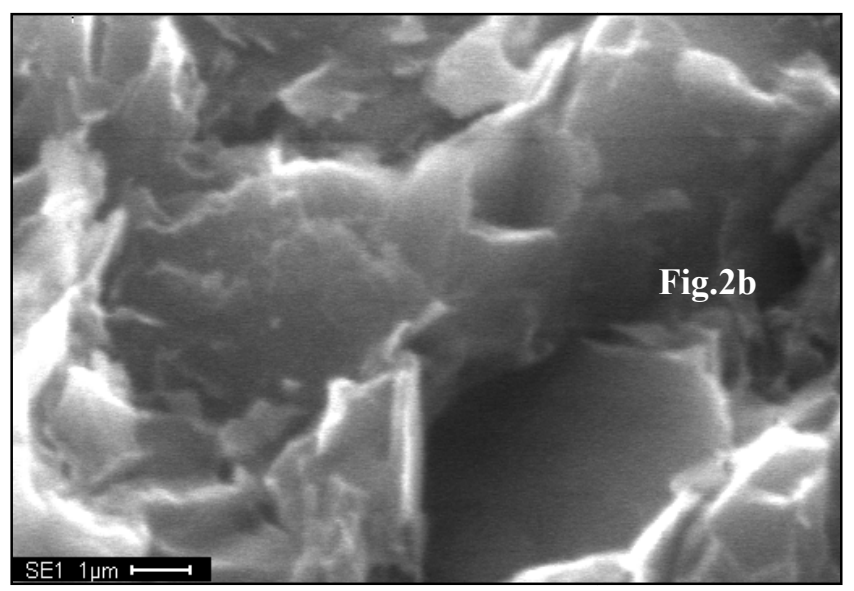

a

Figure. 2a. Back sacttered image of carbonatite lava studied under 10000X.

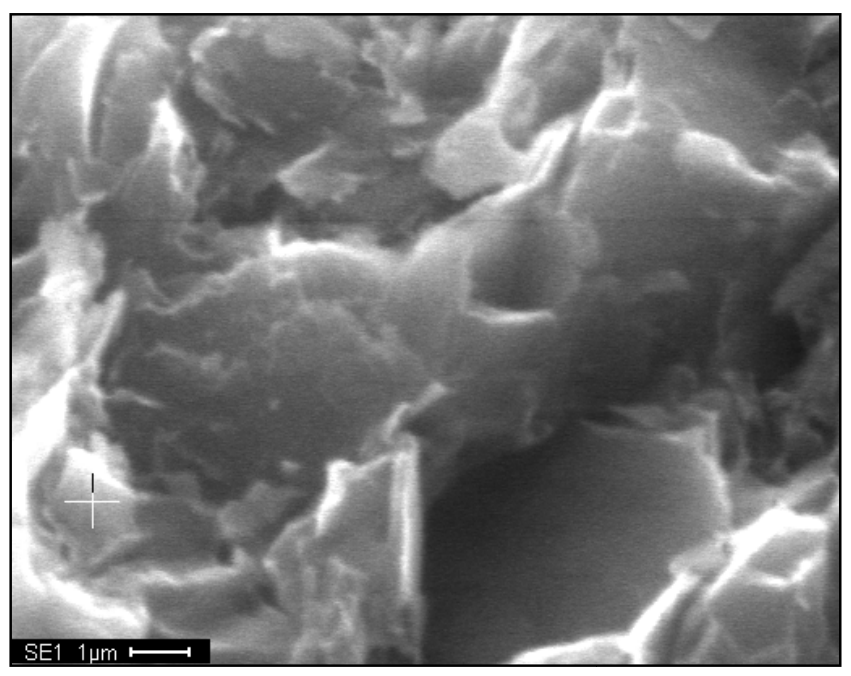

b

Figure. 2b. Back scattered image of carbonatite lava and topaz crystal at the + marker at $10000 X$.

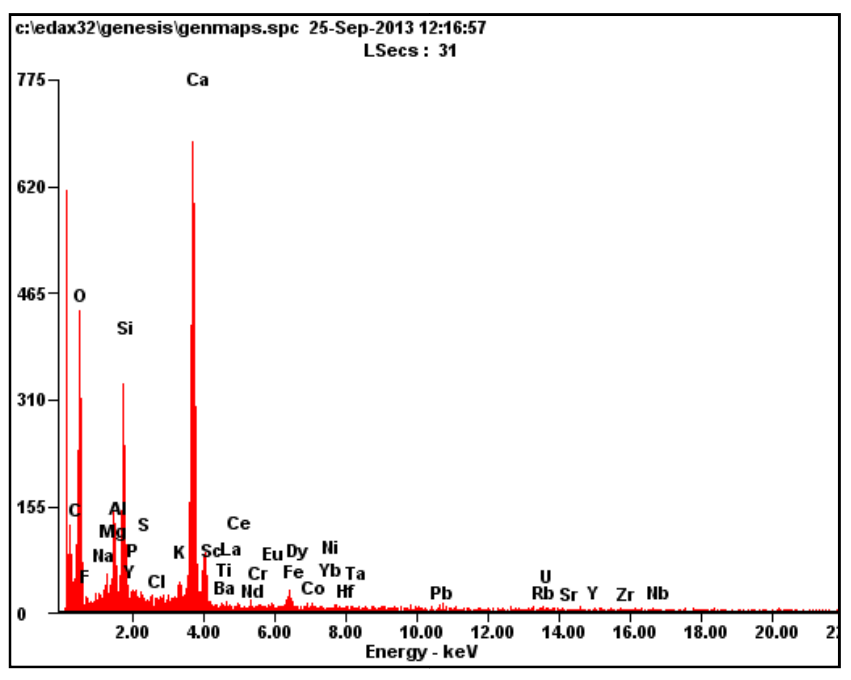

a

Figure. 3a. The composition of topaz crystal.

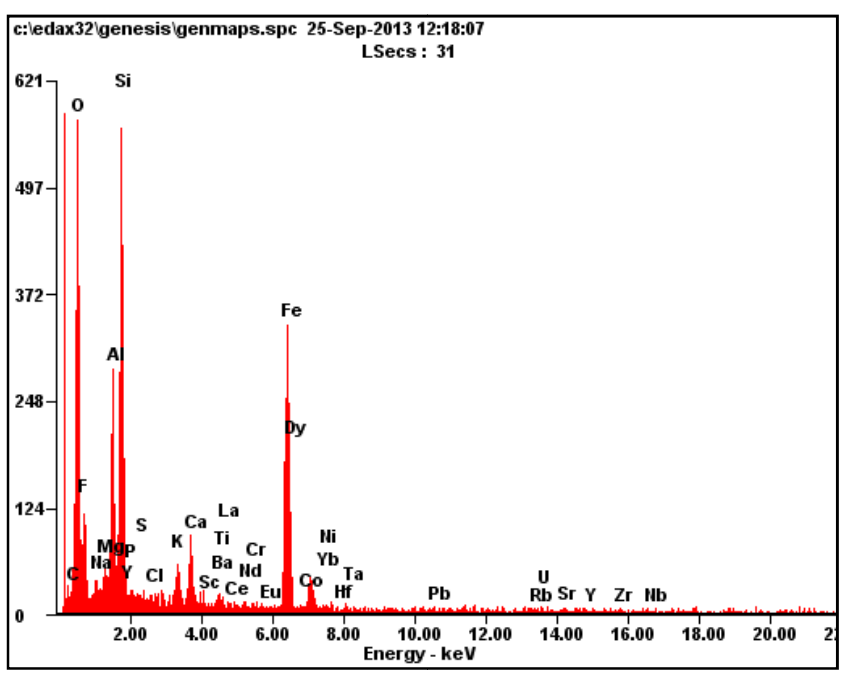

b

Figure. 3 b. The composition of pink carbonatite lava.

\section{Methodology}

Both grey coloured and pink coloured carbonatite lava samples were subjected to EDAX analyses in the Department of Metallurgical and Material Science laboratory, Indian Institute of Technology Madras, Chennai (Fig. 1b and Fig. 2b). The analyses of topaz and the bulk composition of carbonatite lava were recalculated on the basis of their major oxides. They have per cent of $\mathrm{SiO}_{2} 37.63,19.27 ; \mathrm{Al}_{2} \mathrm{O}_{3}$ 14.17, 8.02; $\mathrm{FeO}^{\mathrm{t}}$ 20.61,1.43; $\mathrm{MgO} 1.50,2.95 ; \mathrm{CaO} 2.36,24.35 ; \mathrm{Na}_{2} \mathrm{O}$ 1.32, 1.60; $\mathrm{K}_{2} \mathrm{O} 1.67,1.12 ; \mathrm{TiO}_{2} 0.85,0 ; \mathrm{P}_{2} \mathrm{O}_{5} 0.45,0.53 ; \mathrm{SO}_{3} 0.77$, $0.40 ; \mathrm{H}_{2} \mathrm{O} 5.98,0 ; \mathrm{F} 12.69,2.48$ and $\mathrm{CO}_{2}$ 0, 40.33. On the basis of $24(\mathrm{O}, \mathrm{OH}, \mathrm{F})$ they respectively have $\mathrm{Si} 5.172,1.085$; Al 2.296, 0.532; $\mathrm{Fe}^{+.3}$ 2.133, 0.061; $\mathrm{Mg} 0.307,0.248 ; \mathrm{Ca} 0.347$, 1.468; Na 0.335, 0.175; K 0.293, 0.080; Ti 0.088, 0.0; P 0.053, 0.025; S 0.079, 0.017; OH 5.482, 0; F 5.517, 0.441 and $\mathrm{CO}_{2} 0$, 3.098 ions. 


\section{Results and Discussion}

Topaz consists of $\mathrm{SiO}_{4}$ tetrahedral groups linked together with octahedral groups around Al. Four oxygen ions from $\mathrm{SiO}_{4}$ and 2 anions of $\mathrm{F}$ or $\mathrm{OH}$ surround $\mathrm{Al}$ ions. The structural formula of the topaz is $\mathrm{Si}_{4}\left(\mathrm{Si}_{1.172} \mathrm{Al}_{2.296} \mathrm{Fe}^{3+}{ }_{2.133} \mathrm{Mg}_{0.307} \mathrm{Ca}\right.$ $\left.{ }_{0.347} \mathrm{Na}_{0.335} \mathrm{~K}_{0.293} \mathrm{Ti}_{0.088} \mathrm{P}_{0.053} \mathrm{~S}_{0.079}\right)_{7.104}\left(\mathrm{~F}_{5.517} \mathrm{OH}_{5.482}\right)_{10.998}$. The tetrahedral site greatly enriched $\mathrm{Si}$ ions however the octahedral site is highly deficient in $\mathrm{Al}$ ions. This deficiency of octahedral site could not be compensated by entry of excessive $\mathrm{Si}$ ions and conversion of all the iron into ferric iron and other ions present in the octahedral site. Over saturations of nearly 3 ions of $\mathrm{OH}$ and $\mathrm{F}$ indicate that $\mathrm{OH}$ ions play critical role on the crystallization of topaz from a residual fluid derived from the carbonatite melt in its end stage of consolidation. Approximately 50 per cent of $(\mathrm{OH}, \mathrm{F})$ group taken up by the $\mathrm{OH}$, reveals that it is the highest $\mathrm{OH}$ values so far recorded. Further, F/OH ratio is dependent on the fugacity of $\mathrm{HF}$ and $\mathrm{H}_{2} \mathrm{O}$ at the time of crystallization of the mineral. The deficiency of octahedral group may be compensated by the entry of certain trace elements characteristic of carbonatite melt. The hydroxyl bearing ferrian topaz is an unnamed analogue of topaz ${ }^{4,5,6,7}$. The trace elements in ppm present in the topaz and the bulk composition representing carbonatite respectively are Sc 150,30; Y 630, 390; La 330,110; Ce 370,0;
Nd 230,70; Eu 250,110, Dy 1120,190; Zr 1220, 670; Hf 430, 360; Nb 1260, 500; Ta 340, 200; Pb 980, 800; U 1720, 1120; $\mathrm{Rb} 350,300$ and $\mathrm{Cl}$ 200,70. All these trace elements are relatively more concentrated in the topaz than in the carbonatite tuff. These incompatible elements are characteristically enriched in the residual fluid representing the composition of topaz crystallized from the carbonatitic melt during its final stage of consolidation than the carbonatite lava.

$\mathrm{Si}+\mathrm{Al}$ is generally concentrated during the course of crystallization and fractionation of carbonatite magma. Similarly F as an incompatible element crystallizes only at the late stages of magmatic differentiation as individual minerals. A positive correlation is seen between the co-variation of $(\mathrm{Si}+\mathrm{Al})$ and $\mathrm{F}$ (Figure. 4a). Increase of $\mathrm{F}$ atoms against decreasing $\mathrm{O}$ atoms show the trend of crystallization of topaz. However after reaching a threshold peak, decreasing trend of $\mathrm{F}$ atoms with increasing of $\mathrm{O}$ atoms indicates the concentration of hydroxyl ions during late stages of consolidation of carbonatite lava (Figure 4b). This feature further illustrates that fugacity of water vapour was preceded with development of fugacity of $\mathrm{F}$. The continuous depletion of $\mathrm{F}$ atoms with increasing trend of $\mathrm{O}$ atoms indicates increasing fugacity of water vapour during late stages of consolidation of carbonatitic lava.

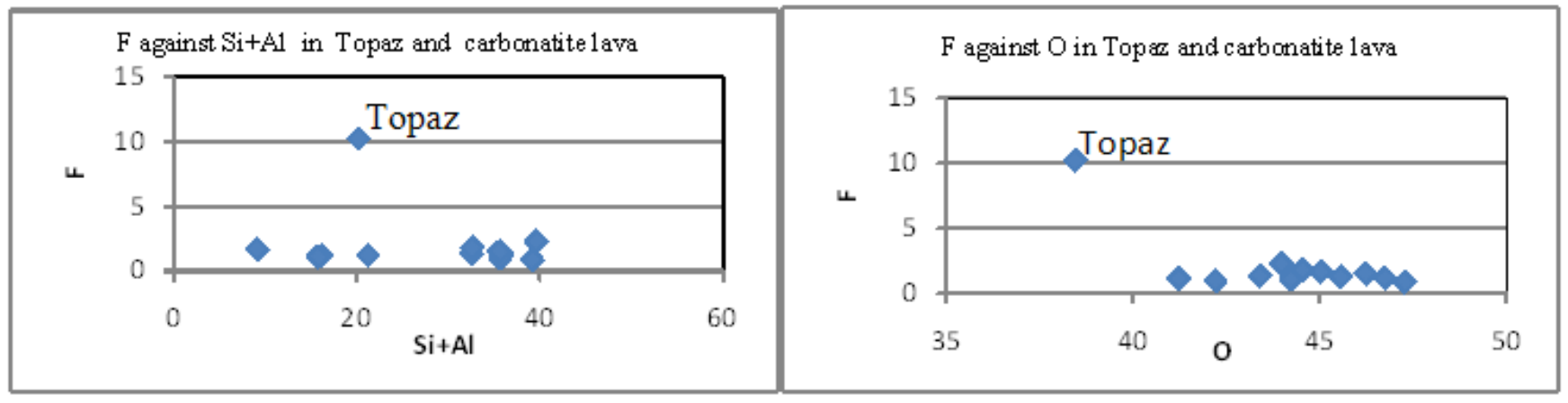

Figure 4. a Distribution of $F$ against (Si+Al) in carbonatites and in topaz. It shows enrichment of $F$ is positively correlated with (Si+Al) enrichment in carbonatite lava; $b$ Distribution of $F$ against $O$ atoms, indicates that enrichment of fugacity of $F$ is just prior to the enrichment of fugacity of water vapour.
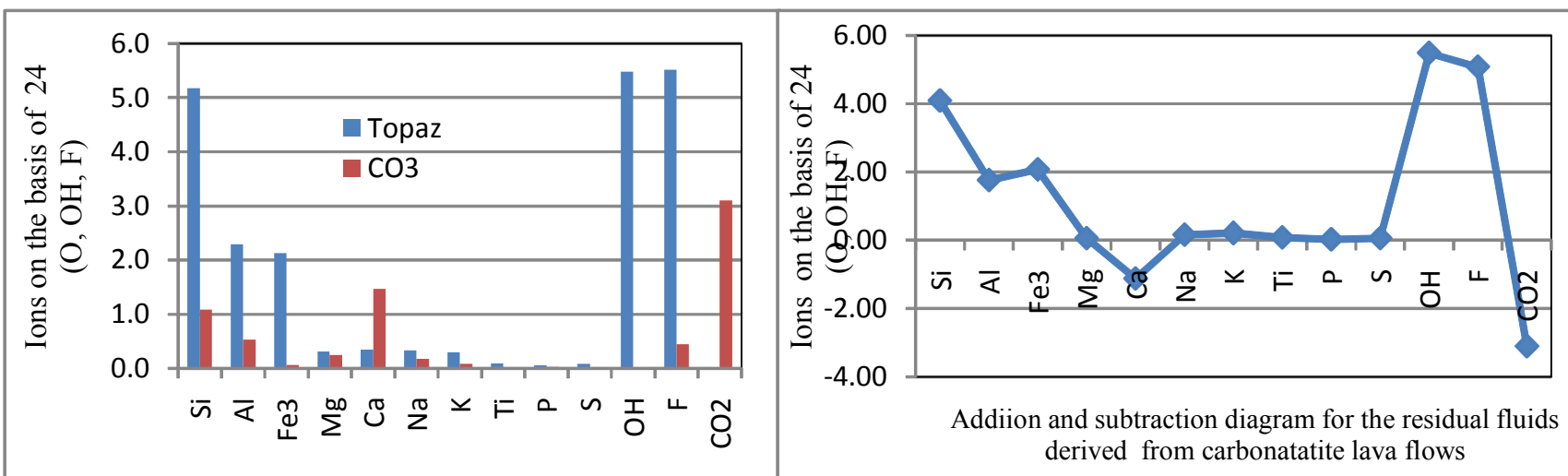

Figure 5. a. Compositional variations between carbonatite lava and its residual fluid (topaz); $b$. Addition and subtraction of ions between carbonatitic fluid and topaz which represents the residual composition derived from carbonatite lava during its rapid consolidation on the Earth surface (on the basis of 24 (O. OH. F). 
Topaz crystallization was affected by gaseous emanations during consolidation of carbonatite lava at low pressure volcanic condition. The bulk composition of the carbonatite lava was undergone bulk chemical change during its eruption or effusion depending up on its volatile content. Under volcanic state, the dissolved gases such as $\mathrm{H}_{2} \mathrm{O}, \mathrm{H}_{2} \mathrm{CO}_{3}, \mathrm{H}_{2} \mathrm{~S}$, $\mathrm{HCl}$, $\mathrm{HF}$, etc. which released from the carbonatite melt concentrate in vesicles, voids and intergranular boundaries of crystallizing minerals. It is conceivable that in the final stages still uncrystallized part of the lava has more resemblance to a solution of mineral matter in superheated state. When solidification is nearly complete, the gases can no longer be retained and make their escape through grain boundaries to vesicles and voids. Aqueous solution dissolved these gases acts as powerful agent in attacking minerals forming topaz, apatite, biotite and other ore-forming minerals. Assuming bulk composition of carbonatite lava representing as the parent material for the crystallization of topaz and the composition of topaz as aqueous residues solution, an addition and subtraction diagram on the basis of $24(\mathrm{O}, \mathrm{OH}, \mathrm{F})$ was constructed (Figure 5a, 5b). This diagram indicates that considerable amount of $\mathrm{Si}, \mathrm{Al}, \mathrm{Fe}^{3+} \mathrm{OH}$ and $\mathrm{F}$ were to be added with depletion of $\mathrm{Ca}$ and $\mathrm{CO}_{2}$ ions. The high concentration of $\mathrm{OH}$ ions indicates that the siliceous carbonatite lava contains significant amount of water vapour in addition to $\mathrm{F}$ ions. $\mathrm{Si}+\mathrm{Al}$ rich carbonatite relatively viscous lava possessed high content of $\mathrm{F}$ and $\mathrm{OH}$ during the course of its rapid consolidation. Relatively greater degree of escape of $\mathrm{OH}$ ions than the escape of $\mathrm{F}$ ions, $\mathrm{F}$ was concentrated during late stage crystallization of topaz. This feature indicates that during eruption or effusion great quantity of water vapour was accompanied with carbonatite lava.

The volcanic rock of carbonatite lava/ tuff was rapidly consolidated under sudden decrease of pressure and temperature to atmospheric state within a few days or hours of duration to achieve equilibrium state at Earth surface after its eruption or effusion. Volatiles concentrated residual fluids were very similar to composition of topaz. Generally, fenitizing residual fluids evolved by crystallization and differentiation leading to comagmatic alkali syenites and carbonatites from nephelinitic parent magma are sodium rich and strongly silica deficient ${ }^{8}$. The fenitizing solutions are strongly alkali and oxidizing. During the course of fenitization of migmatite gneiss around carbonatite quartz, feldspars, biotite and chlorite are replaced by alkali pyroxene and amphibole, nepheline and alkali feldspars. The experimental studies of the system $\mathrm{CaO}-(\mathrm{MgO}+\mathrm{FeO} *)$ $\left(\mathrm{SiO}_{2}+\mathrm{Al}_{2} \mathrm{O}_{3}+\mathrm{TiO}_{2}\right)-\mathrm{CO}_{2}$ at $1 \mathrm{GPa}$ mantle pressure temperature conditions reveal that development of residual solutions of both silica undersaturated alkali rich solution as well as silica over saturated are possible with immiscible boundary of two liquid fields ${ }^{9}$. Occurrence of wollastonite and quartz bearing carbonatites are also common. The presence of topaz, wollastonite, quartz and biotite in the carbonatite lava indicates, the lava was consolidated under high $\mathrm{OH}$ and $\mathrm{F}$ rich conditions. The composition of residual solutions depends upon the initial crystallization and fractionation of silica saturated or undersaturated minerals from chemical composition and nature of the parent magma ${ }^{10}$. During volcanic eruption or effusion of carbonatite lava, its volume increases owing to sudden decrease in pressure. The volume expansion of carbonatite lava releases gaseous constituents and residual aqueous solutions from it. The residual aqueous fluid traversing through intergranular boundaries of subsolidus carbonate minerals was caused crystallization of topaz and biotite at interstitial places of carbonate minerals. The solubility of $\mathrm{Zr}$ in the residual solution increases solubility of hydroxyl ions during crystallization of topaz ${ }^{7}$. Further the crystallization of ferrian topaz indicates its peralkaline nature of the residual solution ${ }^{7}$

\section{Conclusion}

The characteristic enrichment of trace elements of $\mathrm{Zr}, \mathrm{Nb}$, Sr, Y, Sc RE, and U reveals the carbonatitic affinity of the topaz. The very rare occurrence of ferrian hydroxyl topaz in the carbonate rock further confirms pneumatolytic action of carbonatite lava during its final consolidation. Such type of pneumatolytic action usually found in pegmatitic fluids is quite possible during rapid consolidation of a very fluidly carbonatite magma at near surface condition in the course of its eruption due to changes in viscosity of the melt similar to miarolytic crystallization with co-existence of phenocrysts, matrix and vesicles together.. The mode of occurrence of grey and pink coloured carbonatitic bombs, lapillus, pisolites and ash materials in semi-unconsolidated conglomerate lying between Mio-Pliocene sandstone and Pleistocene boulder bed indicates bimodal volcanic activities that took place between these periods in Tamil Nadu.

\section{Reference}

[1] R. Ramasamy, Carbonatite bombs, lapillus, pisolites and ashes in semi-unconsolidated conglomenrates of Early Pleistocene, from Thiruvalangadu, Tamil Nadu, India. IJERA, 2014, v. 4, (8), 1.

[2] R. Ramasamy, Carbonatite-tephriate and bimodal carbonatite lava occurrences in Dharangambadi - Karikal coast, Tamil Nadu, India, IJMSET, 2014, v.1 (6) 15-30.

[3] R. Ramasamy, The Evidences of Late Cenozoic volcano-tectonic deformations in the Kudangulam area near Cape Comorin, Tamil Nadu, Tamil Culture, (1996-2000), 2000, v 14-18, 169-179.

[4] W. A. Deer, R. H. Howie, J. Zussman Rock Forming Minerals, Pear son, Prentice Hall, London, 1986.

[5] B. Wunder, D. C. Rubie, C. R. Rosss, O. Medenbach, F. Seifert, and W. Schreyer, Synthesis, stability and properties of Al2SiO4(OH)2: a fully hydrated analogue of topaz. American Mineralogist, 1993, v.78, 285-297.

[6] R. Y. Zhang, J. G. Liou and J. F. Shu Hydroxyl-rich topaz in high-pressure and ultrahigh-pressure kyanite quartzite, with retrograde Woodhouseite, from the Sulu Terrane, Eastern China. American Mineralogist, 2002 v. 87, pp.445-453. 
[7] www.researchgate.net/.../262342237_REE_and_HF mineralization in peralkaline granites.

[8] Le Bas, M. J. Carbonatite-Nephelinite Volcanism. London: John Wiley, 1977.

[9] Woh-Jer Lee and Wylle, P. J., Petrogenesis of carbonatite magmas from Mantle to crust constrained by the system $\mathrm{CaO}$ $(\mathrm{MgO}-\mathrm{FeO} *)-\left(\mathrm{Na}_{2} \mathrm{O}+\mathrm{K}_{2} \mathrm{O}\right)-\left(\mathrm{SiO}_{2}+\mathrm{Al}_{2} \mathrm{O}_{3}+\mathrm{TiO}_{2}\right)-\mathrm{CO}_{2}$, Journal of Petrology, 1998, 39, 3, pp. 495-517.

[10] Yagi, K. Petrochemical studies on the alkaline rocks of the Morotu District, Sakhalin, GSA Bull, 1953, v. 64, 769-810. 